NBER WORKING PAPER SERIES

AUSTRALIA FAREWELL:

PREDICTORS OF EMIGRATION IN THE 2000S

\author{
Richard V. Burkhauser \\ Markus H. Hahn \\ Matthew Hall \\ Nicole Watson \\ Working Paper 21918 \\ http://www.nber.org/papers/w21918
NATIONAL BUREAU OF ECONOMIC RESEARCH
1050 Massachusetts Avenue
Cambridge, MA 02138
January 2016

This paper uses unit record data from the Household, Income and Labour Dynamics in Australia (HILDA) Survey. The HILDA Project was initiated and is funded by the Australian Government Department of Social Services (DSS) and is managed by the Melbourne Institute of Applied Economic and Social Research (Melbourne Institute). Support for this paper from the Australian Government Department of Social Services (DSS) is cordially acknowledged by Burkhauser, Hahn, and Watson. The findings and views reported in this paper, however, are those of the authors and should not be attributed to DSS, the Melbourne Institute, or the National Bureau of Economic Research. In addition, Burkhauser over the past three years has received funding in excess of $\$ 5,000$ from the American Enterprise Institute; an Australian Research Council Discovery Grant; the Employment Policies Institute; the Lynde and Harry Bradley Foundation Graduate and Post-Graduate Fellowship Program; the Michigan Retirement Research Consortium (from the Social Security Administration), and the Russell Sage Foundation. Hahn over the past three years has received funding in excess of $\$ 5,000$ from an Australian Research Council Discovery Grant. Hall over the past three years has received funding in excess of $\$ 5,000$ from the National Institutes of Health, the National Science Foundation, Pew Research Center, and the Stanford Poverty Center. Watson over the past three years has received funding in excess of $\$ 5,000$ from an Australian Research Council Discovery Grant.

NBER working papers are circulated for discussion and comment purposes. They have not been peerreviewed or been subject to the review by the NBER Board of Directors that accompanies official NBER publications.

(C) 2016 by Richard V. Burkhauser, Markus H. Hahn, Matthew Hall, and Nicole Watson. All rights reserved. Short sections of text, not to exceed two paragraphs, may be quoted without explicit permission provided that full credit, including $(\mathcal{C}$ notice, is given to the source. 
Australia Farewell: Predictors of Emigration in the 2000s

Richard V. Burkhauser, Markus H. Hahn, Matthew Hall, and Nicole Watson

NBER Working Paper No. 21918

January 2016

JEL No. J1,J6

\begin{abstract}
The factors leading individuals to immigrate to developed nations are widely studied, but comparatively less is known about those who emigrate from them. In this paper, we use data from a nationally representative cohort of Australian adults to develop longitudinal measures of emigration and to assess how social ties and individual economic position predict emigration. Cox proportional hazards models indicate that the propensity to emigrate is particularly pronounced for those with relatively little social connectedness in Australia. Specifically, our results show that first-generation Australians, especially those with relatively short durations in the country, have substantially higher emigration rates than later-generation Australians. Similarly, having a partner with deeper generational roots in Australia strongly reduces the likelihood to emigrate. At the same time, our analysis also shows that economic position matters, with the not employed having higher risks of emigration. Perhaps most interestingly, estimates from our models reveal that those with university degrees are much more likely to emigrate than individuals with lower levels of education; a finding that is true for both first- and later-generation Australians.
\end{abstract}

\author{
Richard V. Burkhauser \\ Cornell University \\ Department of Policy Analysis \\ \& Management \\ 259 MVR Hall \\ Ithaca, NY 14853-4401 \\ and University of Melbourne \\ and also NBER \\ rvb1@cornell.edu \\ Markus H. Hahn \\ Melbourne Institute of Applied Economic \\ and Social Research \\ University of Melbourne \\ Faculty of Business and Economics Building \\ 5th floor \\ Victoria 3010, Australia \\ mhahn@unimelb.edu.au
}

\author{
Matthew Hall \\ Cornell University \\ Department of Policy Analysis \\ and Management \\ mhall@cornell.edu \\ Nicole Watson \\ Melbourne Institute of Applied Economic \\ and Social Research \\ Level 5, Faculty of Business \\ and Economics Building \\ University of Melbourne VIC 3010 \\ n.watson@unimelb.edu.au
}




\section{Australia Farewell: Predictors of Emigration in the 2000s}

The pace of global migration has steadily risen. As a result, about one in every 30 persons is now an international migrant. The demographic impacts of international migration are widespread, but perhaps nowhere more profoundly than in Australia, which houses nearly 5\% of all the international migrants living in developed countries (United Nations 2013). Immigrants now compose more than a quarter of the Australian population, making the foreign-born share in Australia the fourth largest among OECD countries. Moreover, immigration has not only fueled population change in Australia but has transformed social, economic, and political institutions in major ways. Yet, the full consequences of immigration depend not only on the inflows and composition of newcomers but on the extent to which those migrants selectively stay in Australia; i.e., on the outflow of emigrants.

Owing to data limitations, the measurement of emigration has long posed a challenge to demographers. Whereas data on vital events—-births and deaths_-are readily available in most developed countries, and immigration to a country can be determined through cross-sectional surveys on residents’ birth countries, emigration cannot as easily be ascertained. The conventional solution has been to determine emigration flows through the compilation of administrative data on immigration into all possible destinations (see Abel 2013). This approach not only is limited by the comparability of the collection of data sets, but largely prevents researchers from describing detailed information on the characteristics of individuals who emigrate. $^{1}$

A basic understanding of the rate of emigration is fundamental to understanding the total social and economic impacts of immigration. These impacts, however, are shaped not just by the 
levels of emigration but also by its selectivity. Thus comprehending who is leaving Australia provides insights on not only why they are leaving but also what the selective impacts may be. With respect to the net effect of the growing number of migrants on the educational or occupational mix of the Australian work force, understanding the selective nature of emigration has implications for assessing the success of immigration policies in retaining skilled workers. More directly, it is of great importance to understand the roles that economic opportunities and family/co-ethnic networks play in shaping emigration decisions.

In this paper, we use data from the Household, Income, and Labour Dynamics in Australia (HILDA) Survey to assess rates of emigration and describe characteristics that are associated with the decision to emigrate. The nationally representative and longitudinal nature of the HILDA Survey, combined with a detailed accounting of nonresponse, allows us to provide representative profiles of Australian emigrants and to test theoretical arguments about their reasons for departure.

\section{Background}

Emigration is undoubtedly the least studied component of the demographic equation. The bureaucratic challenge of tracking exits across national borders combined with the difficulty in determining both the permanency and destination of their moves makes the estimation of emigration challenging. While the mechanisms behind emigration have been understudied, we do know that emigration processes carry major social and economic implications. Emigration, for example, has been shown to reduce unemployment (Funkhouser 1992) and consequently raise wages for non-migrants (Lucas 1987); but it is also often associated with reductions in human capital and losses of government investments in education (Beine, Docquier, and Rapoport 2001), and it has been linked to reduced consumption and rising consumer prices (see 
Asch 1994). Emigration also has the potential to destabilize families and disrupt the fabric of community civic life, but also to improve the well-being of the families of migrants that are left behind (Funkhouser 2006).

Owing to its aquatic borders and a concerted effort to track migration events, Australia is one of only a few countries that attempt to monitor all international moves, both immigration and emigration. Historically, this has been based on analysis of required Passenger Cards that identify the direction (in- vs. out-migration) and intention (temporary vs. permanent) of each migration event. However, because of a high prevalence of “category jumping”-i.e., temporary migrants settling permanently, and vice versa—stated intentions paint an incomplete picture of the nature of emigration outcomes (see Lukomskyj and Richards 1986). Consequently, since 2006, migration intentions reported on Passenger Cards are no longer used to determine in- or out-flows in official statistics. Instead long-term migrants are identified as those who remained in (out of) the country for at least 12 of the 16 months following a move (see Productivity Commission 2010). Linking the Passenger Cards to information from passports makes it possible not only to enumerate the number of Australians who emigrate annually, but to characterize emigration along a few sociodemographic characteristics, including age, gender, place of birth, occupation, and destination country (see, for instance, Australian Bureau of Statistics 2012a; Birrell et al. 2004; Hugo 1994; Hugo, Rudd, and Harris 2001).

To demonstrate the utility of these data and to emphasize the role of emigration in contributing to Australian population change, we combine Passenger Card data and vital events from the Australian Bureau of Statistics (ABS) for the 2001-2006 period. Specifically, Table 1 shows yearly births and deaths (natural increase) and yearly immigration and emigration (net overseas migration) based on the one-year threshold (i.e. 12 months out of 12 months) the ABS 
used over this period for long-term arrivals and departures. The table shows that, for each year between 2001 and 2006, overseas immigration is a more important source of total population growth than births, and emigration is a more important drag on population growth than deaths. Or stated in another way, emigration attenuates the role of immigration in substantial ways, offsetting around two of every three new immigrants each year. In the only year over this period that we are able to estimate the net overseas migration of prime working-age people (aged 2554), emigration is an even larger drag on immigration, offsetting nearly three of every four new immigrants. $^{2}$

\section{(TABLE 1 ABOUT HERE)}

\section{Predicting Emigration}

Our analysis of ABS data reveals that emigration plays an important role in Australian population change. Yet, the impact of emigration is a function not just of the magnitude of the flow but of its composition. While the ABS Passenger Card data contain some basic information on the characteristics and traits of Australian emigrants, they lack critical information on the family structure and generational status necessary to assess the role of acculturation and family networks on the risk of exit. These data also do not include information on the educational attainment of emigrants one needs to evaluate how human capital shapes emigration.

Accordingly, prior work on selection in Australian emigration processes has been based on other data sets. Hugo et al. (2001), for example, use the Longitudinal Survey of Immigrants to Australia (LSIA 1) that follows immigrants who arrived in Australia in the early 1990s, as well as the Graduate Destination Surveys (GDS) of recent university graduates. Hugo, Rudd, and Harris (2003) use the 2002 Australian Emigration Survey, a postal and online survey capturing Australian expatriates in the United Kingdom, United States, and some Asian countries. While 
these data sets are rich in socioeconomic characteristics, they are not representative of the full emigrant population.

Conceptually, we draw on theoretical models of migration from demography, economics, and sociology that emphasize the roles of human and social capital in structuring the likelihood of emigration. There is no singular theory of migration among social scientists (Massey et al. 1998), though economists have tended to emphasize the potential for financial returns to migration (Sjaastad 1962; Stark 1991) while sociologists have highlighted the roles of social networks and cultural/ethnic resources in the migration process (de Haas 2014; Massey 1990).

More specifically, economic theory predicts that the likelihood of emigration is higher for the unemployed and other workers with low wages. These same models generally argue that, in developed nations, persons with higher levels of education have broader labor market search strategies and resources that allow for greater mobility. However, whether this translates into greater overseas migration depends on the market for skilled labor in a person's home country relative to other countries (Borjas 1989; Borjas and Bronars 1991; Stark 1991). The migration of highly educated workers has been a major topic of academic research. What began as research focused on the international brain drain from developing to developed countries has increasingly focused on the return of emigrants to their home country-e.g., migration as development or “brain gain” (e.g., Bijwaard 2010; Borjas 1996; Constant and Zimmermann 2012; Docquier and Rapoport 2012; and Thomas 2008).

While human capital models emphasize the role of skills and the potential economic benefits produced by migration, theories of social capital argue that social connectedness factors importantly into migration decisions. More specifically, the family and social ties that individuals have in an origin country—e.g., through family roots, kin networks, ethnic 
communities, or just time in the country-likely weaken the desire to migrate by increasing the costs—both psychic and financial—of leaving.

Prior work in other developed nations has largely been consistent with these basic arguments for emigration. In a study of return migration among German guest workers using the German Socio-Economic Panel (SOEP), Constant and Massey (2002) find evidence that emigrants exhibit behavior consistent with an income-maximizing strategy but are not differentiated based on education, age, or gender. They find, however, that social attachments (e.g., presence of a spouse or children) and civic attachments (e.g., becoming a German citizen) were strongly associated with remaining in Germany, while the maintenance of transnational ties (e.g., via remittances) increased the likelihood of emigration.

Also using the SOEP data, Steiner and Velling (1992) found that guest workers’ intentions to stay in Germany were strongly tied to measures of social attachment: having young children, speaking the host language, and owning a house increased intentions to stay, while remitting, unemployment, and having children in the origin country reduced intentions to remain in Germany. Similarly, Waldorf (1995) studied migration intentions of German guest workers using several cross-sectional surveys and found strong support for the role of job and residential satisfaction on return intentions and differences by age but little effect of gender or marital status. Reagan and Olsen (2000) used the U.S. National Longitudinal Study of Youth to study return migration of immigrants and found people with higher potential wages and those who had been in the U.S. longer were more likely to remain but those who undertook college degrees were more likely to leave.

Our goal in this analysis is to provide evidence on the characteristics associated with emigration from Australia. The timing of this issue is of particular salience given not just the 
spike in immigration that Australia has experienced over the last several decades, but because of sustained economic growth since the start of the $21^{\text {st }}$ century. ${ }^{3}$ To do so, we use longitudinal data from the Household, Income and Labour Dynamics in Australia (HILDA) Survey that represents a random sample of the resident population of Australia. With these data, we are able to estimate yearly and cumulative risks of emigration for working-age Australians between 2001 and 2011, and assess how these risks are conditioned by theoretically- relevant characteristics of individuals. We are especially interested in differences in exit risk by generational ties to Australia and educational attainment, characteristics not available in the Australian Passenger Card data or passport information.

\section{Data and Methods}

We use data from the 2001-2013 waves of HILDA, a nationally representative household panel study that began in 2001 with 13,969 respondents in 7,682 households. The reference population is all people living in private dwellings, excluding those in very remote parts of Australia. Faceto-face interviews are conducted annually with all household members aged 15 years and older and detailed socio-economic information is collected from each respondent (see Watson and Wooden (2012) for more details about HILDA). We use all currently available waves of data (2001-2013).

\section{Measuring Emigration}

One of the key benefits of using HILDA is that the longitudinal nature of the survey allows us to identify the timing and duration of exits from Australia by leveraging annual information on respondents' interview status. ${ }^{4}$ Specifically, HILDA uses a detailed follow-up procedure to determine whether a respondent has left the country based on international contact (via email or phone) with the respondent or (most often) notification by household members, friends, or 
former neighbors that they have emigrated. In such cases, a person who is not in the household because s/he is overseas is retrospectively classified as being an emigrant when they are (or expect to be) overseas for more than 12 months. In some cases, a sample member's location cannot be determined in a given year; we exclude these time points from our analysis except in rare situations. ${ }^{5}$

To model emigration, we use survival analysis to show how the yearly hazard rate of exit varies by individual characteristics. In each year from 2001 through 2011, a person in our sample will reside either in or out of Australia. But to consider the exit long term, we require the person to exit Australia and not return for at least two years. (Findings using alternative time thresholds are available in an unpublished appendix available from the authors.)

From 2001 to 2005 the ABS used a one-year threshold and later expanded it to 12 out of the next 16 months. The choice of threshold affects the total number of exits that are considered long term. The longer the duration of the threshold, the fewer the number of long-term emigrants captured in the data, but the less likely that they will return. This can be seen in Table 2 where we follow all those in the original HILDA sample who left Australia in Wave 2. In Row 1 we use a one-year threshold. In each succeeding row we extend our threshold by one year. The greatest loss in emigrants occurs when we move from a one- to a two-year threshold. But our reason for not using the one-year threshold mirrors that of the ABS—a substantial share of emigrants return.

The panel nature of our data allows us to look over a much longer time period than did the ABS and more systematically demonstrate this relationship. To better compare the percentage of returners across the different thresholds, we limit the window over which we observe a return to eight years in each row. ${ }^{6}$ As can be seen $31.2(21.0) \%$ of long-term emigrants 
return some time over our eight-year window for our entire sample (working-age sample). The share returning is much less when we expand our threshold to two years, $22.0 \%$ in the full sample but not much different in the working-age sample (19.6\%). In the working-age sample, which is the main focus of our analysis, there is no change in the percentage of emigrants who return when we further expand the threshold. Therefore, in this paper, we exclusively use the two-year threshold to define and analyze long-term exits. ${ }^{7}$

\section{(TABLE 2 HERE)}

We first use Nelson-Aalen estimates to determine the cumulative hazard rates of emigrating by age group for our entire 2001 Australian population disaggregated by first, second, and third-plus (or “deeper-rooted”) generation Australians to provide some context for the cohort of working-age Australians we follow in all subsequent tables. In the main part of our analysis, we focus on working-age adults (aged 25 to 54) because we are primarily interested in the broader impacts of emigration on labor supply and want to ensure that our analytic sample draws on individuals who have likely completed schooling and who are unlikely to be retired. Restricting our analysis to our working-age sample, we then use Kaplan-Meier estimates to determine the yearly hazard and cumulative survival rates of all those aged 25-54 and living in Australia in 2001 and then again disaggregating by first, second, and deeper rooted Australians. In our final set of estimates, we employ Cox proportional hazard models for our aged 25-54 sample and then disaggregate first generation Australians from all other Australians. ${ }^{8}$ In determining the level of significance in our tables we control for clustering by households, since it is likely that decisions to exit by one household member (most often the partner) will importantly affect the decision to exit of other household members.

\section{Independent Variables}


To assess the argument that social connections impact the likelihood of migration—namely that deeper social ties reduce the risk of emigration—we incorporate measures of generational status that distinguish between the first-generation (those not born in Australia), second-generation (those born in Australia but whose mother or father was not born in Australia), and those with deeper generational roots (those whose mother and father were both born in Australia). We further disaggregate first generation Australians by the number of years they have lived in Australia, hypothesizing that the longer the duration of their stay, the greater their Australianspecific network social capital. While generation status is a fixed characteristic, duration in Australia (for the first generation) is allowed to vary over time. An additional reason to include this measure of time in Australia for immigrants is to capture temporary immigrants, both students and workers who entered the country on provisional visas. To minimize the number of temporary students in our working-age sample, we only include residents who were at least age 25 in 2001. But not all temporary students will in fact leave once their studies are completed. Importantly, as early as 1999, students entering the country on temporary visas who then graduated from an Australian educational institution were awarded additional points in determining their eligibility for permanent residence (see Productivity Commission 2010).

Temporary workers are more likely than students to be in our 2001 working-age sample. In 1996 Australia initiated a Temporary Business (Long Stay) subcategory visa that allowed holders to work in Australia for up to four years without renewal. (See Cobb-Clark [2003]; Khoo et al. [2007]; and Gregory [2014] for a fuller discussion of changes in visa policies in the 1990s and beyond and how they have affected the characteristics of new immigrants and the mix of temporary to permanent visa holders in Australia.) So the exit of these temporary workers is also 
likely to increase the risk of early exits during the 2000s. ${ }^{9}$ We thus disaggregate first generation immigrants into those living in Australia: 0-4 years, 5-14 years, and 15 or more years.

We consider the argument that both family ties and social connectedness alter decisions to emigrate through a measure of partnership disaggregated by generation status of one's partner. Specifically, we use a (time-varying) five-component generational categorization: partnered with a first-generation immigrant living in Australia (0-4 years, 5-14 years, and 15 or more years); partnered with a second-generation Australian; and partnered with someone that has a deeper rooted family history in Australia. While we expect those with partners to be less likely to emigrate, we expect those with second generation or greater partners to be less likely to do so than those with first generation partners since such partners add even more social capital to the partnership in the form of their family's Australian-specific network.

Relevant socioeconomic characteristics for testing arguments about the role of human capital and economic conditions include: education attainment (grouped into those with less than a high school degree, those with a high school degree but no more, and those with a university degree); annual employment (time-varying); and time-varying annual real income (post tax and transfer income adjusted for household size and inflation). ${ }^{10}$ We also incorporate relevant demographic characteristics, including age, gender, and the presence and age of children.

\section{Results}

We start our analysis by estimating overall emigration rates and—based on the HILDA population weights—-the total number of people who emigrated from Australia during the 2000s. The results summarized in Table 3 show that of the 18.82 million residents living in Australia in 2001, 878,894 (4.67\%) are estimated to have emigrated by $2011 .{ }^{11}$ Yet, the rates of emigration vary substantially by age and generation. The oldest (aged 55 and over) and youngest (aged 0- 
14) age cohorts had the lowest exit rates (1.68 and 2.82\% respectively) while those aged 15-24 had the highest rates (13.42\%). Our prime working-age cohort, which made up 42.7\% (8.04 million) of the total Australian population in 2001, had a cumulative exit rate of 4.39\%.

\section{TABLE 3 HERE}

Shown in the subsequent columns of Table 3 are emigration rates (by age) for each of the major generational groups. In the next three columns we disaggregate our sample into first, second, and deeper rooted generation Australians. (Because the HILDA Survey does not interview those under age 15, we can only provide cumulative exit rates for our three older cohorts.) The age pattern of exit rates is broadly consistent across generations, with younger cohorts having higher cumulative exit rates and older cohorts having lower cumulative exit rates than the prime working-age cohort. Most importantly, the results indicate that the cumulative risk of emigration is especially pronounced for first-generation immigrants, with exit rates that are two to three times larger than comparably aged second- and deeper-generation Australians. The especially high exit rates for the first generation Australians (29.85\%) in the aged 15-24 cohort may, in large part, be the result of students with temporary visas returning to their home countries. Similarly, the high exit rates of second and deeper rooted generation Australians aged 15-24 may include some students leaving to study abroad but who eventually return. Among the prime-working age cohort, for example, first-generation Australians have a high cumulative exit rate (9.12\%) that is three times that of second generation Australians and nearly five times that of deeper rooted Australians.

In Figure 1 we graph the yearly risks of exit through 2011 for the cohort of Australians aged 25-54 in 2001. Specifically, we show the cumulative survival curve, which shows the running likelihood that an individual will remain in Australia by the end of a survey year, 
separately for the pooled sample (grey line), and each of the broad generation groups. As seen in Figure 1, the largest drop in the overall survival rate—and thus the highest rate of emigrationoccurs in the first period, after which it declines steadily. When we disaggregate our sample into first (solid black line), second (dashed black line), and deeper rooted generation Australians (dotted black line), we see that survivorship is much lower—and thus, the risk of exit much higher—for first-generation Australians than for second or more deeply rooted generation Australians in all periods. This is especially so over the first four years, in part because some portion of this first generation of immigrants was likely admitted on temporary visas, but also potentially because they have fewer social and economic ties to Australia. It is also apparent that second generation Australians have somewhat lower survivorship rates (and, thus, higher exit rates) than the more deeply rooted $\left(3^{\text {rd }}+\right)$ generation Australians, especially over the first five periods.

\section{FIGURE 1 HERE}

The descriptive patterns in the previous figure suggest that emigration is conditioned by age and generation status. To more formally test arguments that the risk of emigration is influenced by social and economic characteristics of individuals and households, we report results from a multivariate Cox proportional hazard model of risk of exiting Australia for the 2001 working-age population in Table 4. To consider the possibility that the correlates of emigration differ by generation status, we additionally show results from models separately for first-generation and higher-generation $\left(2^{\text {nd }}+\right)$ Australians.

\section{TABLE 4 HERE}

Consistent with our descriptive results, Table 4 shows that the newest immigrants have particularly high risks of exit. Relative to the deeper-rooted Australians, those who arrived in 
Australia less than five years ago are 9.78 times more likely to exit, those who have lived in Australia for 5-14 years are 3.73 times more likely, and those who have been in Australia for at least 15 years are 2.23 times more likely to emigrate. (All of these differences are statistically significant at the $1 \%$ level.) Again, while our focus on 25 to 54 year olds likely excludes most student migrants, at least part of the reason for the high emigration rates of the newest arrivals reflects the possibility that they hold temporary visas. In contrast to the foreign-born, second generation Australians are 20\% more likely to exit than third generation Australians, but the difference is not significant. Hence even when we control for socioeconomic and demographic factors expected to predict emigration for differences in the risk of an exit, we find that first generation Australians have a significantly higher risk of an exit over their working life relative to more deeply rooted Australians. ${ }^{12}$

The model estimates also indicate that the risk of a partnered person exiting Australia each year relative to a single person also depends on the family history of his or her partner. Those partnered to second generation and more deeply rooted Australians are significantly less likely—by $69 \%$ and 66\%, respectively—to exit Australia than a single person. In contrast, those partnered to recently arrived first generation Australians are not significantly different in their exit rates than are single persons. Thus, the lower tendency of partnered persons to emigrate is limited (statistically) to those whose partners are born in Australia ( $2^{\text {nd }}$ or higher generations). In terms of educational skills, the results in Table 4 indicate that more highly educated persons have especially pronounced rates of emigration. Specifically, the estimates suggest that those with a university degree are 3.24 times as likely to emigrate as those with less than a high school degree (significant at the $1 \%$ level), while those with no more than a high school degree are $73 \%$ more likely to emigrate than those without a high school degree (significant at the $5 \%$ 
level). ${ }^{13}$ In Australia, even during a decade of sustained economic growth, both absolutely and compared to the OECD average, it was those with greater levels of human capital that left Australia.

The socioeconomic and demographic predictors tend to operate in expected directions. Holding constant other characteristics in the model, those who are not employed have rates of emigration that are 1.93 times higher than those of employed persons, household incomes are positively tied to emigration, and age, gender, and the presence of young children are all significant predictors of emigration.

Our results based on our sample of prime-age adults confirm that first generation immigrants, especially those who had more recently come to Australia, had a significantly higher risk of an exit than either second generation or deeper rooted generations. This relationship between weak social ties to Australia and a heightened risk of an exit also extends to the issues of partnership. Specifically, our estimates suggest partnership inhibits emigration, but only to the extent to which the partner has relatively established roots in Australia (i.e., was born in Australia or is a long-term immigrant).

To investigate whether these last two relationships are consistent within generations, we now compare their associations for first-generation (Column 2) and second and higher generation Australians (Column 3). We combine these last two generational groups in our Column 3 model since we found no significant difference between them in their risk of an exit in our full prime working-age sample. The results in Column 2 for first-generation immigrants confirm the importance of time since arrival, with the most recent among this generation of immigrants to Australia having especially high rates of exit. Specifically, our estimates suggest that firstgeneration immigrants who have lived in Australia for fewer than 5 years are 5.95 times more 
likely, and those having lived in Australia for between 5 and 14 years 1.98 times more likely to exit than first-generation immigrants with longer stays.

In terms of partnership and human capital, our results indicate that these characteristics do not predict emigration in significantly different ways for first and older generation Australians. The estimates in Columns 2 and 3 reveal that having a partner with deeper Australian roots is associated with a reduced risk of emigration, regardless of generation status. Similarly, highly educated persons exhibit substantially higher emigration rates than those without a high school degree, for both first-generation and higher-generation Australians.

The remaining characteristics in the model also tend to operate similarly across the generation groups. Individuals who are out of work exhibit higher risks of emigration for both first and higher-order generations (albeit not significantly so for the higher-generation group). Similarly, income is positively associated with emigration for both groups, although not significantly so for first generation immigrants. Emigration rates decline with age, and—for firstgeneration immigrants—are lower among women than men.

\section{Discussion and Conclusions}

Measuring emigration has long been a challenge for demographers and other social scientists; yet we know that the social impacts of emigration on a country are profound. Not only does emigration affect population change, but the composition of emigration flows has major implications for social institutions and local economies. To the extent that emigration is part of a system of immigrant return migration, its magnitude and makeup also speak to broader debates about the effectiveness of national immigration policies. These issues are of particular relevance in Australia where one-in-four persons are foreign-born, and concerns about the responsiveness of immigration policies have grown. Our purpose in this paper has been to describe these flows 
of people out of Australia over the first decade of the $21^{\text {st }}$ century. In addition to estimating overall rates of emigration, we focus on the individual social and economic characteristics most strongly related to the risk of emigration.

Using panel data from the HILDA Survey, we employ a Cox proportional hazards model to estimate the risk of leaving the country for a nationally representative sample of Australians. Results from these models indicate that individuals with weaker ties to Australia are, as expected, much more likely to emigrate than those with deeper connections. Specifically, our findings indicate that first-generation immigrants have particularly high rates of exit. Though first-generation migrants represented less than 30\% of prime-age Australians in 2001, they made up nearly two-thirds (63.2\%) of those who left Australia by 2011. The high rates of emigration were particular pronounced for the newest immigrants-those in the country for less than five years. While we attempted to exclude student migrants by restricting the age of our sample, certainly part of the explanation for the very high exit rate among the newest Australians is that some were admitted under temporary visas and either did not intend to stay longer or were unable to do so. Yet we also found significantly higher exit rates for first generation groups who, over the decade we followed them, stayed well past the point permitted with a temporary visa.

Consistent with arguments about the role of social connectedness in shaping migration decisions, we find strong evidence that the generational roots of one's partners are related to emigration. In particular, our estimates indicate that being partnered to a second or third generation Australian substantially lowers the risk of emigration, among both first and higherorder generation Australians. Along these same lines, we also find that having young children reduces the risk of exiting the country. 
While weaker social linkages to Australia were highly predictive of emigration, we also find strong support for arguments that economic considerations play an important role in the migration process. Among the stronger correlates of emigration is employment: persons without a job are twice as likely to emigrate as those who are currently employed. At the same time, our results also imply that better-educated persons and those with higher incomes have substantially higher risks of emigration. Based on our rate estimates of emigration, we approximate that of the 2.02 million with a university degree in 2001, 8.20\% permanently left Australia over the next decade. This is far higher than the 3.65\% risk for the 3.58 million Australians with a high school but less than a university degree and the $1.66 \%$ risk for the 2.71 million Australians with less than a high school degree.

Without detailed information (lacking in HILDA data) on where these individuals are migrating to, we are unable to determine the underlying mechanisms that lead to the emigration of skilled persons, but future work would profit from considering this issue more closely. Regardless, the high rates of skilled emigration may be viewed as concerning to the extent that these individuals are unable to find work in Australia commensurate with their education. Australia already suffers from a notable "skills gap" in terms of labor shortages in skilled sectors (Department of Employment 2015), so the loss of educated workers may further aggravate labor demands. It is noteworthy that this finding is not limited to first-generation immigrants. Indeed, with controls for other socioeconomic and demographic characteristics, our results indicate that the risk of emigration is at least as strong among university-educated Australian natives $\left(2^{\text {nd }}+\right.$ generations) as it is among immigrants. Thus, this loss of human capital is potentially a significant drag on future economic growth and partly offsets the major policy efforts in Australia to increase the stock of high-skill workers. 
International migration has been accelerating for the last several decades and concerns about the impact of migrants on national economies, political systems, and cultural life pervade policy discussions. Australia, like many other developed countries, has long been characterized as a nation of immigrants. The intense focus in major immigrant-receiving countries, like Australia, on how to incorporate foreigners and protect natives from any adverse impacts too often overlooks the counterflow of residents outside of the national borders. As we have shown in this paper, emigration - even in 'immigrant nations' - is a substantial component of population change and is selective of individuals with weaker generational and familial ties. But we also found, as noted above, that it is the most highly educated who have the strongest proclivities to out-migrate. The broader implications of these outflows are conditioned by their largely unknown impacts. On the one hand, the loss of skilled workers may contribute to labor shortages in a way that promotes policies focused on the retention of skilled labor (e.g., providing settlement assistance and relaxing requirements for transitioning from temporary and permanent residence for skilled migrants). On the other hand, emigration is likely to offer some benefits, not only in the form of welfare gains to individual migrants, but in the form of a greater global linkages and skills that may be brought home. 


\section{Endnotes}

${ }^{1}$ Docquier and Rapoport (2012) review a primarily economics-based literature focusing on "brain drain" issues that has estimated emigration stocks and rates of emigration indirectly at the country level for over 195 countries in 1990 and 2000. For instance, a source country emigration stock is estimated by summing the stock of foreign-born residents of OECD countries using receiving countries' census data in those years to estimate the source country's emigration stock in that year by skill level, education, and gender. The source country's rate of brain drain is then calculated using this value as the numerator and this value plus the source country's census data for those years as the denominator. Parallel sociology-based literatures exist using this technique to focus on emigration from a country or group of countries to a specific country. See Thomas (2011) for a good example. He captures emigration of Africans to the United States using United States immigration information.

${ }^{2}$ In an appendix available from the authors we extend this table to the years 2006-2011. However, since 2006 the ABS has used a " 12 out the next 16 months threshold" so these later year values are not consistent with those in Table 1. But they do show that emigration continues to be an important drag on immigration.

${ }^{3}$ Over the first decade of the 21st century, Australia's average economic growth was $3.1 \%$, substantially higher than the OECD average of 1.7\%. Furthermore, unlike most other OECD countries, while Australia's yearly economic growth slowed over the Global Finance Crisis, it always remained positive (OECD 2014).

${ }^{4}$ As Docquier, Lowell, and Marfouk (2009:302) note, Australia is one of the few countries whose official statistics provide a realistic picture of emigration. Unlike the ABS, which at most only follows immigrants and emigrants for 16 months in defining them as transitory or permanent, we are able to determine how many of those we define as emigrants in our samplethose who we observed in the country in 2001 but not in Australia at some point later for two consecutive waves of the HILDA Survey data-do eventually return to Australia.

${ }^{5}$ If a person's location in a given year (or streak of years) is “Unknown” but that person's location in the following year is "Overseas," we change that person's location from "Unknown" to "Overseas." That is, we assume that this person went overseas at the time the location is unknown. Subsequently, we exclude time points when a person's location is still "Unknown" (14.4\% of all time points) or when a person is "Deceased" (3.5 \% of all time points). Our survival analysis procedures treat these excluded time points as censored.

${ }^{6}$ HILDA only provides a true random sample of the Australian population in 2001 and we only focus on this population cohort. But to hold the number of years following an exit constant, we must use different years in each row and the maximum window is eight since our last wave of data is 2013.

${ }^{7}$ In an appendix, available upon request, we also provide analyses using one-year, three-year, and four-year thresholds. 
${ }^{8}$ A person contributes data as long this person is alive and their location is known; otherwise they are right-censored. The population in this last sample is smaller $(n=7,653)$ than in our aged 25-54 sample since we only include those for whom we have complete information on all dependent variables.

${ }^{9}$ Since 1973 citizens of New Zealand and Australia have been allowed to travel, work, and live in either country without being required to apply for entry permission. This especially complicates the determination of temporary and permanent departures for this population of emigrants from Australia which we are unable to directly control in the HILDA data because we do not know emigrants' destinations. See Sanderson (2009) for an analysis of the complex repeat and return migration patterns through June 2005 of New Zealand citizens who permanently arrived in Australia between August 1999 and July 2002 based on the old ABS "12 consecutive months in the country" definition. For a more general discussion of the theoretical problems related to prediction of circular migration, see Massey (1987) and Massey and Espinosa (1997) in the context of the United States and Mexico.

${ }^{10}$ In supplemental models, we considered an additional lag on employment and income to account for the possibility that individuals make labor market changes in anticipation of an international move. The results from these models (in an appendix available from the authors upon request) produce results that are substantively and statistical similar to those shown here.

${ }^{11}$ In addition, we calculated these values without population weights and using HILDA 20012012 longitudinal weights. The level of risk changed slightly (decreasing in the former and increasing in the latter case) but the relative risks remained approximately the same. More details are in an appendix available from the authors upon request.

${ }^{12}$ We also find a significantly higher risk when we compare first to second generational Australians in this model.

${ }^{13}$ These two values are also significantly different from one another in this model. 


\section{References}

Abel, G. J. (2013). Estimating global migration flow tables using place of birth data. Demographic Research, 28, 505-546.

Asch, B. J. (Ed.) (1994). Emigration and its effects on the sending country. Santa Monica: Rand Corporation

Australian Bureau of Statistics. (2003). Migration, Australia, 2000-01 and 2001-02 (ABS catalogue no. 3412.0). Accessed 14/04/2014.

Australian Bureau of Statistics. (2012a). Leaving Australia forever? Australian social trends (ABS catalogue no. 4102.0). Accessed 14/04/2014.

Australian Bureau of Statistics. (2012b). Deaths, Australia, 2011 (ABS catalogue no. 3302.0). Accessed 14/04/2014.

Australian Bureau of Statistics. (2013). Migration, Australia, 2011-12 and 2012-13 (ABS catalogue no. 3412.0). Accessed 14/04/2014.

Australian Bureau of Statistics. (2014). Australian demographic statistics, Sep 2013 (ABS catalogue no. 3101.0). Accessed 14/04/2014.

Beine, M., Docquier, F., \& Rapoport, H. (2001). Brain drain and economic growth: Theory and evidence. Journal of Development Economics, 64(1), 275-289.

Bijwaard, G. E. (2010). Immigrant migration dynamics model for The Netherlands. Journal of Population Economics, 23, 1213-1247.

Birrell, R. J., Rapson, V. J., Dobson, I., Smith, T. F. (2004). Skilled movement in the new century: Outcomes for Australia. Department of Immigration and Multicultural \& Indigenous Affairs, Canberra ACT Australia, 1-103.

Borjas, G. J. (1989). Economic theory and international migration. International Migration Review, 23(3), 457-485.

Borjas, G. J. (1996). Who leaves? The outmigration of the foreign-born. The Review of Economics and Statistics, 78, 165-176.

Borjas, G. J., \& Bronars, S. G. (1991). Immigration and the family. Journal of Labor Economics, 9, 123-148.

Cobb-Clark, D. A. (2003). Public policy and the labor market adjustment of new immigrants to Australia. Journal of Population Economics, 16(4), 655-681.

Constant, A., \& Massey, D. S. (2002). Return migration by German guestworkers: Neoclassical versus new economic theories. International Migration, 40(4), 5-36. 
Constant, A. F., \& Zimmermann, K. F. (2012). The dynamics of repeat migration: A Markov chain analysis. International Migration Review, 46(2), 362-388.

de Haas, H. (2014). Migration theory: Quo Vadis? International Migration Institute Working Paper Series No. 100, University of Oxford.

Department of Employment. (2015). Skills shortages - Statistical summary. Labour Market Research and Analysis Branch, 2014-15, Australian Government.

Docquier, F., Lowell, B. L., \& Marfouk, A. (2009). A gendered assessment of highly skilled emigration. Population and Development Review, 35(2), 297-321

Docquier, F., \& Rapoport, H. (2012). Globalization, brain drain, and development. Journal of Economic Literature, 50(3), 681-730.

Funkhouser, E. (1992). Mass emigration, remittances, and economic adjustment: The case of El Salvador in the 1980s. In G. J. Borjas \& R. B. Freeman (Eds.), Immigration and the workforce: Economic consequences for the United States and source areas (pp. 135-176). University of Chicago Press.

Funkhouser, E. (2006). The effect of emigration on the labor market outcomes of the sender household: a longitudinal approach using data from Nicaragua. Well-Being and Social Policy, 2(2): 5-25.

Gregory, R. G. (2014). The two-step Australian immigration policy and its impact on immigrant employment outcomes. IZA DP No. 8061, March.

Hugo, G. J. (1994). The economic implications of emigration from Australia, AGPS, Canberra.

Hugo, G., Rudd, D., \& Harris, K. (2001). Emigration from Australia: Economic implications. CEDA Information Paper no. 77, CEDA, Melbourne.

Hugo, G., Rudd, D., \& Harris, K. (2003). Australia's diaspora: Its size, nature and policy implications. CEDA Information Paper no. 80, CEDA, Melbourne.

Khoo, S.-E., MacDonald, P., Voigt-Graf, C., \& Hugo, G. (2007). A global labor market: Factors motivating the sponsorship and temporary migration of skilled workers to Australia. International Migration Review, 41(2), 480-510.

Lucas, Robert E. B. (1987). Emigration to South Africa’s mines. American Economic Review, 77, 313-330.

Lukomskyj, O., \& Richards, P. (1986). Return migration from Australia: A case study. International Migration, 24(3), 603-623.

Massey, D. S. (1987). Understanding Mexican migration to the United States. American Journal of Sociology, 92(6), 1372-1403. 
Massey, D. S. (1990). Social structure, household strategies, and the cumulative causation of migration. Population Index, 56(1), 3-26.

Massey, D. S., Arango, J., Hugo, G., Kouaouci, A., Pellegrino, A., \& Taylor, J. E. (1998). Worlds in motion: Understanding international migration at the end of the millennium. Oxford: Oxford University Press.

Massey, D. S., \& Espinosa, K. E. (1997). What's driving Mexico-US migration? A theoretical, empirical and policy analysis. American Journal of Sociology, 102(4), 939-999.

OECD. (2014). OECD. Stat extracts: GDP, volume - annual growth rates in percentage. http://stats.oecd.org. Accessed 24/04/2014.

Productivity Commission. (2010). Population and migration: Understanding the numbers. Commission Research Paper, December.

Reagan, P. B., \& Olsen, R. J. (2000). You can go home again: Evidence from longitudinal data. Demography, 37(3), 339-350.

Sanderson, L. (2009). International mobility of new migrants to Australia. International Migration Review, 43(2), 292-331.

Sjaastad, Larry A. (1962). The costs and returns of human migration. Journal of Political Economy, 70(5), 80-93.

Stark, O. (1991). The migration of labor. Oxford, UK: Basel Blackwell.

Steiner, V., \& Velling, J. (1992). Re-migration behavior and expected duration of stay of guestworkers in Germany. ZEW Discussion Papers, No. 92-14.

Thomas, K. J. A. (2008). Return migration in Africa and the relationship between educational attainment and labor market success: Evidence from Uganda. International Migration Review, 42(3) 652-674.

Thomas, K. J. A. (2011). What explains the increasing trend in African emigration to the U.S.? International Migration Review, 45(1), 3-28.

United Nations. 2013. Trends in international migrant stock: The 2013 revision. United Nations database, POP/DB/MIG/STOCK/Rev.2013.

Waldorf, B. (1995). Determinants of international return migration intentions. The Professional Geographer, 47(2), 125-136.

Watson, N., \& Wooden, M. (2012). The HILDA survey: A case study in the design and development of a successful household panel study. Longitudinal and Life Course Studies, 3(3), 369-381. 
Figure 1: The Cumulative Survival Rates of an Exit for the Australian Population Aged 25-54 in 2001 by Generational Background

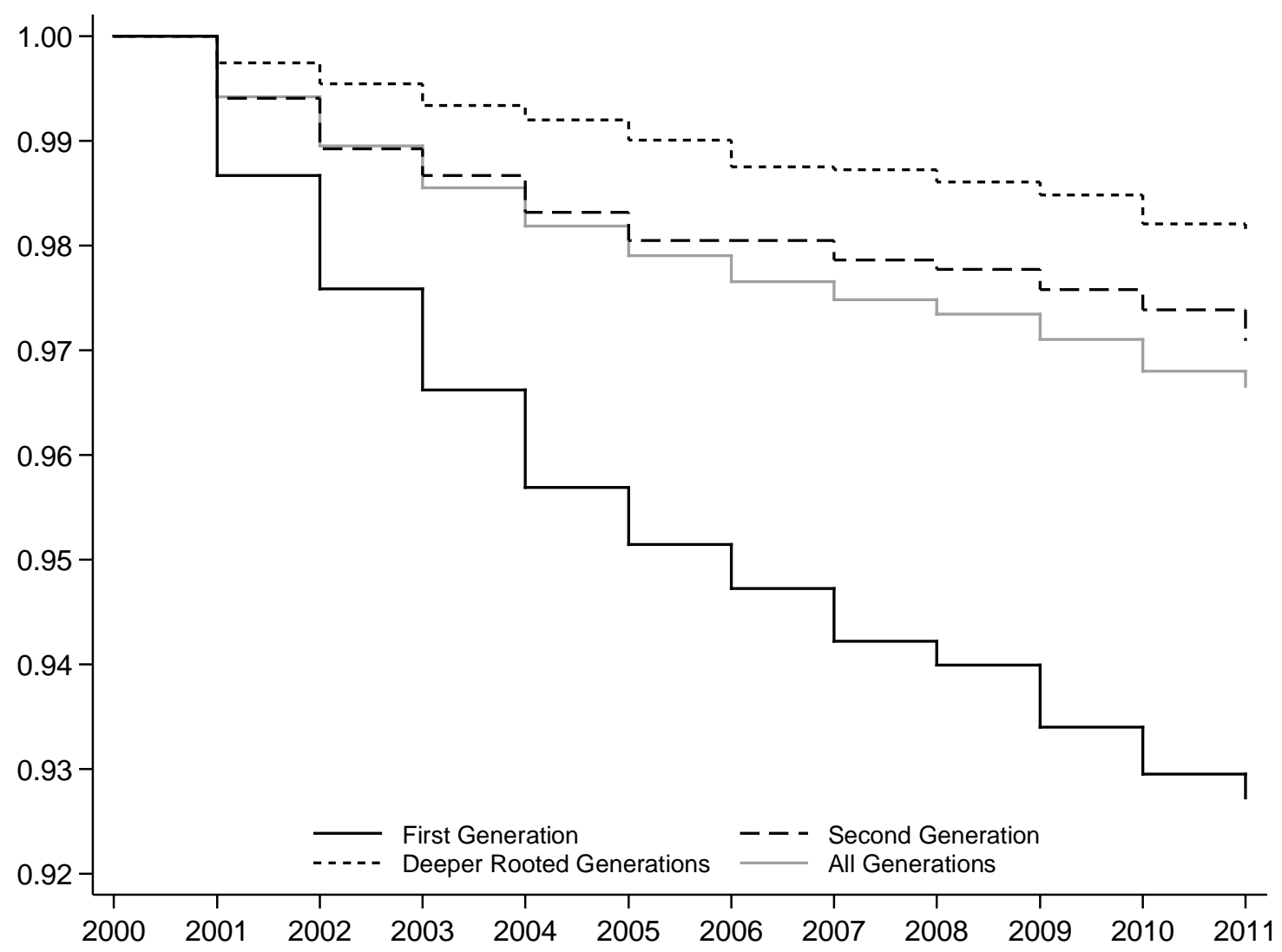

Source: Authors’ calculations based on HILDA (2001-2013) 
Table 1: Components of Australian Population Yearly Growth (2001-2006 $)$

\begin{tabular}{|c|c|c|c|c|c|c|}
\hline & Births & Deaths & $\begin{array}{c}\text { Natural } \\
\text { Increase }^{b}\end{array}$ & $\begin{array}{l}\text { Overseas } \\
\text { Arrivals }^{c}\end{array}$ & $\begin{array}{c}\text { Overseas } \\
\text { Departures }\end{array}$ & $\begin{array}{c}\text { Net } \\
\text { Overseas } \\
\text { Migration }^{\mathrm{d}}\end{array}$ \\
\hline & \multicolumn{3}{|c|}{1,000 persons } & \multicolumn{3}{|c|}{1,000 persons } \\
\hline \multicolumn{7}{|l|}{ All ages } \\
\hline 2001-02 & 249.4 & 130.2 & 119.2 & 339.2 & 228.6 & 110.6 \\
\hline 2002-03 & 249.2 & 132.2 & 116.9 & 350.1 & 233.6 & 116.5 \\
\hline 2003-04 & 252.0 & 133.2 & 118.8 & 360.6 & 260.7 & 100.0 \\
\hline 2004-05 & 258.3 & 131.4 & 126.9 & 392.6 & 269.0 & 123.8 \\
\hline 2005-06 & 266.1 & 134.0 & 132.0 & 423.8 & 277.2 & 146.7 \\
\hline \multicolumn{7}{|c|}{ Ages 25-54 } \\
\hline 2001-02 & \multirow{2}{*}{\multicolumn{3}{|c|}{$\frac{12.5^{\mathrm{e}}}{\% \text { of population stock }}{ }^{\mathrm{f}}$}} & 182.0 & 135.9 & 46.1 \\
\hline & & & & \multicolumn{3}{|c|}{$\%$ of population stock ${ }^{f}$} \\
\hline \multicolumn{7}{|l|}{ All ages } \\
\hline 2001-02 & 1.29 & 0.68 & 0.62 & 1.76 & 1.19 & 0.57 \\
\hline 2002-03 & 1.28 & 0.68 & 0.60 & 1.80 & 1.20 & 0.60 \\
\hline 2003-04 & 1.28 & 0.68 & 0.60 & 1.83 & 1.32 & 0.51 \\
\hline 2004-05 & 1.30 & 0.66 & 0.64 & 1.97 & 1.35 & 0.62 \\
\hline 2005-06 & 1.32 & 0.66 & 0.65 & 2.10 & 1.37 & 0.73 \\
\hline \multicolumn{7}{|c|}{ Ages 25-54 } \\
\hline 2001-02 & & $0.15^{\mathrm{e}}$ & & 2.15 & 1.61 & 0.55 \\
\hline
\end{tabular}

Sources: The all ages statistics come from Australian Bureau of Statistics (2014) with some authors' adjustments. The ages 25-54 statistics come from ABS (2003, 2012b) with some authors' adjustments. The author's adjustments are discussed in the notes below.

Notes:

${ }^{a}$ Years in this table do not refer to calendar years but to Australian financial years which start on 1 July and end on 30 June.

${ }^{\mathrm{b}}$ This is births minus deaths.

c We assume the "migration adjustment" values for these years is proportionately distributed between arrivals and departures holding net overseas migration values constant. See ABS (2013).

${ }^{d}$ This is overseas arrivals minus overseas departures where those who arrive (depart) both intended to permanently migrate and they remained in (out of) the country for the next year.

${ }^{\text {e }}$ We approximated financial year deaths using the mean value of deaths reported in calendar years 2001 and 2002 from ABS (2012b).

${ }_{\mathrm{f}}^{\mathrm{f}}$ For all ages, the population stocks for 2001-02, 2002-03, 2003-04, 2004-5, and 2005-06 are 19,274.7, 19,495.2, 19,720.7, 19932.7, and 20,176.8 (1,000 persons). For those aged 25-54, the population stock is 8,446.8 (1,000 persons). Because the population stock values are revised over time, by the ABS, but the flow numbers are not, the growth in the stock value each year will not exactly equal the sum of the flow values from the previous year. 
Table 2: Number of Returns of Those Exiting in Wave 2 by the Length of Their Minimum Overseas Spell

\begin{tabular}{|c|c|c|c|c|c|c|}
\hline \multirow[b]{2}{*}{ Stay overseas at least } & \multicolumn{3}{|c|}{ All persons } & \multicolumn{3}{|c|}{ 25-54 year olds } \\
\hline & $\begin{array}{c}\text { Number of } \\
\text { exits in } \\
\text { Wave } 2 \\
\end{array}$ & $\begin{array}{c}\text { Stay } \\
\text { overseas } \\
(\%) \\
\end{array}$ & $\begin{array}{c}\text { Return from } \\
\text { overseas } \\
(\%) \\
\end{array}$ & $\begin{array}{l}\text { Number of } \\
\text { exits in } \\
\text { Wave } 2 \\
\end{array}$ & $\begin{array}{c}\text { Stay } \\
\text { overseas } \\
(\%) \\
\end{array}$ & $\begin{array}{c}\text { Return from } \\
\text { overseas } \\
(\%) \\
\end{array}$ \\
\hline 1 year or more & 141 & 68.8 & 31.2 & 62 & 79.0 & 21.0 \\
\hline 2 years or more & 118 & 78.0 & 22.0 & 56 & 80.4 & 19.6 \\
\hline 3 years or more & 112 & 82.1 & 17.9 & 56 & 80.4 & 19.6 \\
\hline 4 years or more & 111 & 82.0 & 18.0 & 56 & 80.4 & 19.6 \\
\hline
\end{tabular}

Source: Authors' calculations based on HILDA (2001-2013)

Notes: Persons that exit in Wave 2 are followed for eight years after they completed their minimum overseas spell. 
Table 3: Australian Population by Age Cohorts in 2001 and the Number and Cumulative Risk of an Exit through 2011 by Generational Background

\begin{tabular}{|c|c|c|c|c|c|c|c|c|}
\hline \multirow{2}{*}{$\begin{array}{l}\text { Age group } \\
\text { (years) }\end{array}$} & \multicolumn{2}{|c|}{ Total Persons $^{\mathrm{a}}$} & \multicolumn{2}{|c|}{ First Generation $^{b}$} & \multicolumn{2}{|c|}{ Second Generation $^{\mathrm{b}}$} & \multicolumn{2}{|c|}{$\begin{array}{c}\text { Deeper Rooted } \\
\text { Generations }\end{array}$} \\
\hline & $\begin{array}{l}\text { Number }^{\mathrm{c}} \\
\text { (million) }\end{array}$ & $\begin{array}{c}\text { Risk } \\
(\%)\end{array}$ & $\begin{array}{l}\text { Number }^{\mathrm{c}} \\
\text { (million) }\end{array}$ & $\begin{array}{c}\text { Risk } \\
(\%)\end{array}$ & $\begin{array}{l}\text { Number }^{\mathrm{C}} \\
\text { (million) }\end{array}$ & $\begin{array}{c}\text { Risk } \\
(\%)\end{array}$ & $\begin{array}{l}\text { Number }^{\mathrm{c}} \\
\text { (million) }\end{array}$ & $\begin{array}{c}\text { Risk } \\
(\%)\end{array}$ \\
\hline $0-14$ & 3.96 & 2.82 & & & & & & \\
\hline $15-24$ & 2.82 & 13.42 & 0.52 & 29.85 & 0.74 & 12.16 & 1.48 & 9.10 \\
\hline $25-54$ & 8.04 & 4.39 & 2.34 & 9.12 & 1.40 & 3.08 & 4.24 & 1.91 \\
\hline 55 or over & 3.99 & 1.68 & 1.31 & 4.35 & 0.56 & $0.00^{*}$ & 2.09 & $0.35^{*}$ \\
\hline Total & 18.82 & 4.67 & & & & & & \\
\hline
\end{tabular}

Source: Authors' calculations based on HILDA (2001-2013)

Notes:

${ }^{\text {a }}$ Based on the full HILDA sample.

${ }^{\mathrm{b}}$ This sample excludes those persons whose generational background are unknown, hence numbers in these columns do not sum to Total Persons column numbers. Those aged 0-14 were not asked where they were born.

${ }^{\mathrm{c}}$ Based on 2001 HILDA cross-sectional weights.

${ }^{*}$ Estimate is unreliable due to sample size. 
Table 4: Alternative Hazard Models of an Exit for the Australian Population Aged 25-54 in 2001 (Cox Proportional Hazard model)

\begin{tabular}{|c|c|c|c|}
\hline Hazard ratios & Full sample & First Generation & $\begin{array}{c}\text { Second and } \\
\text { Deeper Rooted } \\
\text { Generations }\end{array}$ \\
\hline First Generation Australian (0-4 years) & $\begin{array}{l}9.78^{* * *} \\
(2.69)\end{array}$ & $\begin{array}{l}5.95 * * * \\
(1.92)\end{array}$ & \\
\hline First Generation Australian (5-14 years) & $\begin{array}{l}3.73 * * * \\
(0.75)\end{array}$ & $\begin{array}{l}1.98^{* * *} \\
(0.44)\end{array}$ & \\
\hline First Generation Australian (15 years) & $\begin{array}{l}2.23^{* * *} \\
(0.41)\end{array}$ & & \\
\hline Second Generation Australian & $\begin{array}{l}1.20 \\
(0.24)\end{array}$ & & $\begin{array}{l}1.15 \\
(0.24)\end{array}$ \\
\hline \multicolumn{4}{|l|}{ Deeper Rooted Generation Australian (Omitted) } \\
\hline \multicolumn{4}{|l|}{ Single (Omitted) } \\
\hline Partnered with First Generation Australian ( $0-4$ years) & $\begin{array}{c}0.58 \\
(0.24)\end{array}$ & $\begin{array}{c}0.48 \\
(0.22)\end{array}$ & $\begin{array}{c}0.58 \\
(0.59)\end{array}$ \\
\hline Partnered with First Generation Australian (5-14 years) & $\begin{array}{c}0.95 \\
(0.24)\end{array}$ & $\begin{array}{c}0.76 \\
(0.24)\end{array}$ & $\begin{array}{l}1.15 \\
(0.57)\end{array}$ \\
\hline Partnered with First Generation Australian (15+ years) & $\begin{array}{r}0.64^{*} \\
(0.16)\end{array}$ & $\begin{array}{c}0.57 \\
(0.20)\end{array}$ & $\begin{array}{c}0.64 \\
(0.25)\end{array}$ \\
\hline Partnered with Second Generation Australian & $\begin{array}{l}0.31 * * * \\
(0.09)\end{array}$ & $\begin{array}{l}0.30 * * \\
(0.14)\end{array}$ & $\begin{array}{l}0.32 * * * \\
(0.13)\end{array}$ \\
\hline Partnered with Deeper Rooted Generation Australian & $\begin{array}{l}0.34^{* * *} \\
(0.08)\end{array}$ & $\begin{array}{l}0.32 * * * \\
(0.12)\end{array}$ & $\begin{array}{l}0.40 * * * \\
(0.12)\end{array}$ \\
\hline University degree & $\begin{array}{l}3.24 * * * \\
(0.81)\end{array}$ & $\begin{array}{l}2.69 * * * \\
(0.95)\end{array}$ & $\begin{array}{l}3.36 * * * \\
(1.14)\end{array}$ \\
\hline High school but less than university degree & $\begin{array}{l}1.73^{* *} \\
(0.38)\end{array}$ & $\begin{array}{l}1.99 * * \\
(0.63)\end{array}$ & $\begin{array}{l}1.26 \\
(0.41)\end{array}$ \\
\hline Less than a high school degree (Omitted) & & & \\
\hline Control Variables: & & & \\
\hline Not employed & $\begin{array}{l}1.93^{* * * *} \\
(0.37)\end{array}$ & $\begin{array}{l}2.07 * * * \\
(0.53)\end{array}$ & $\begin{array}{l}1.59 \\
(0.47)\end{array}$ \\
\hline Employed (Omitted) & & & \\
\hline Log of equalized real household income & $\begin{array}{l}1.65 * * * \\
(0.28)\end{array}$ & $\begin{array}{l}1.37 \\
(0.28)\end{array}$ & $\begin{array}{l}2.16^{* * *} \\
(0.53)\end{array}$ \\
\hline Age & $\begin{array}{l}0.92^{* * *} \\
(0.01)\end{array}$ & $\begin{array}{l}0.94 * * * \\
(0.01)\end{array}$ & $\begin{array}{l}0.90^{* * *} \\
(0.01)\end{array}$ \\
\hline Female & $\begin{array}{l}0.78^{* *} \\
(0.09)\end{array}$ & $\begin{array}{l}0.66^{* * *} \\
(0.11)\end{array}$ & $\begin{array}{c}0.89 \\
(0.16)\end{array}$ \\
\hline Children aged $0-4$ years & $\begin{array}{c}0.59^{*} \\
(0.16)\end{array}$ & $\begin{array}{c}0.65 \\
(0.22)\end{array}$ & $\begin{array}{c}0.55 \\
(0.22)\end{array}$ \\
\hline Children aged 5-17 years & $\begin{array}{c}0.97 \\
(0.20)\end{array}$ & $\begin{array}{c}1.32 \\
(0.34)\end{array}$ & $\begin{array}{c}0.66 \\
(0.23)\end{array}$ \\
\hline $\begin{array}{l}\text { Number of Persons } \\
\text { Number of Permanent Leavers }\end{array}$ & $\begin{array}{l}7,650 \\
215\end{array}$ & $\begin{array}{c}1,912 \\
113\end{array}$ & $\begin{array}{c}5,738 \\
102\end{array}$ \\
\hline
\end{tabular}

Source: Authors' calculations based on HILDA (2001-2013). The sample is not weighted.

Notes: Clustered (by household id) standard errors in parentheses. Coefficient estimates that statistically differ from zero are denoted by $* * *, * *$, and $*$ for $\mathrm{p}$-values $\leq .01, \leq .05$, and $\leq .10$ respectively. 